\title{
Development of Freeze-Dried Red Dragon Fruit Yoghurt Containing Probiotics
}

Phát triển sản phẩm sữa chua thanh long đỏ sấy đông khô có chứa probiotic

\author{
Ho Phu Ha, Vu Thu Trang*, Nguyen Chinh Nghia, Vu Hong Son \\ School of Biotechnology and Food Technolgy, Hanoi University of Science and Technology, Hanoi, Viet Nam \\ *Email: trang.vuthu@hust.edu.vn
}

\begin{abstract}
Yoghurt, a product prepared by fermentation of milk with bacterial cultures consisting of Lactobacillus delbrueckii subsp. bulgaricus and Streptococcus thermophilus, has been popular for a long time, however, dehydrated yogurt is still uncommon. Freeze drying is well-known as an effective method to preserve the nutritional and sensory characteristics of the food product compared to other dehydration ways. This study developed a protocol to produce freeze-dried yoghurt fermented by commercial probiotic starter culture containing betacyanin - a bioactive component from red dragon fruit on laboratory scale. The freeze-dried red dragon yoghurt was produced by the following steps: (1) plain yoghurt preparation: Milk with $12 \%$ milk dry matte was heated at $95^{\circ} \mathrm{C}$ for $5 \mathrm{~min}$, cooled down to $42^{\circ} \mathrm{C}$, followed by the addition of commercial probiotic bacteria starter, then fermented for 3 hours until the $\mathrm{pH}$ reached to 4.6 and the milk coagulated (2) obtained yoghurt was mixed with $30 \%$ red dragon fruit, molding in the tray (3) Freeze at $-20^{\circ} \mathrm{C}$ and freezedried (4) packaging to obtain the final product. Betacyanin - well-known as a bioactive compound from red dragon fruit of the obtained products and viable bacteria remained during 30 days storage at room temperature.
\end{abstract}

Keywords: Red dragon fruit, yoghurt, freeze-dried, probiotic

Tóm tắt

Sữa chua, sản phẩm được sản xuất bằng cách lên men sữa với chủng vi khuẩn lactic Lactobacillus delbrueckii subsp. bulgaricus và Streptococcus thermophilus, đã xuất hiện từ rất lâu nhưng sản phẩm sữa chua sấy khô vẫn chưa phải là sản phẩm phổ biến. Sấy đông khô được biết đến là phương pháp giữ lại tốt nhất các đặc tính dinh dương và cảm quan của sản phẩm so với các phương pháp sấy khô khác. Nghiên cứru này đã phát triển qui trình sản xuất sữa chua sấy đông khô lên men bằng chủng lợi khuẩn, có chứa betacyanin - thành phần hoạt chất sinh học từ quả thanh long đỏ trên quy mô phòng thí nghiệm. Dựa trên kết quả nghiên cứu quy trình sản xuất sữa chua thanh long đỏ sấy đông khô có chứa lợi khuẩn được đề xuất theo quy trình sau: (1) dịch sữa được chuẩn bị với nồng độ chất khô từ sữa $12 \%$, gia nhiệt thanh trùng $o^{\prime} 95^{\circ} \mathrm{C}$ trong 5 phút, làm nguội đến nhiệt độ lên men $42^{\circ} \mathrm{C}$, bổ sung chủng lợi khuẩn thương mại, lên men trong 3 giờ tới khi $\mathrm{pH}$ sản phẩm đạt 4.6 và sữa đông tụ (2) sữa chua được phối trộn với $30 \%$ thịt quả thanh long đỏ, đổ khuôn (3) làm đông $-20^{\circ} \mathrm{C}$ và sấy đông khô (4) bao gói. Quy trình này đã giảm thiểu nhiều công đoạn và thiết bi tương ứng với từng công đoạn như ủ hoàn nguyên ở $4{ }^{\circ} \mathrm{C}$ trong $24 \mathrm{~h}$, đồng hóa, bổ sung chất ổn định. Thành phần betacyanin có được từ quả thanh long đỏ và mật độ chủng lợi khuẩn vẫn bảo tồn trong 30 ngày bảo quản sản phẩm ở nhiệt độ thường.

Từ khóa: Sữa chua, thanh long đỏ, sấy đông khô, probiotic

\section{Introduction}

Yoghurt is one of the fermented dairy products most consumed worldwide, due to its nutritional value, healthy effects [1]. Yoghurt is made from various milk, rich in nutrients and includes lactic acid bacteria Lactobacillus delbrueckii subsp. bulgaricus and Streptococcus thermophilus, which have an important role in balancing the digestion and absorption of the body. The final products are also more suitable than other milk products for lactose

ISSN: 2734-9381

https://doi.org/10.51316/jst.153.etsd.2021.31.4.3

Received: April 04, 2020; accepted: September 01, 2020 intolerant individuals [2]. Fruit yoghurts are always preferred among the dairy products and become the main products in all dairy factories in Vietnam $(12 \%$ of the dairy market in Vietnam in 2017). Adding fruits to yoghurt help to diversify products with delicious, typical fruity flavors, and improves overall appearance. Moreover, healthy benefits can come from yoghurt as well as added tropical fruits. However, similar to plain yoghurt, its shelf life is short comparing with other dairy products and strickly required low temperature for transportation and storage. 
Red dragon fruit (Hylocereus polyrhizus) provides humans with essential nutrients such as vitamins, minerals, complex carbohydrates, dietary fibres and antioxidants. Dragon fruit is also an essential source of betacyanin which serves as a red/purple pigment with antioxidative properties [3]. In Vietnam, most of the fresh dragon fruits are consumed domestically, while some are traded as dry fruit and processed products like juice. Therefore, the intensive processing of Dragon fruit is a challenge for food factories in Vietnam.

Freeze-dried foods can be easily transported at normal temperatures, stored for a long period of time, and consumed with a minimum of preparation [4]. Freeze-drying consists in reducing water from a product by sublimation, defined as the passage of water from solid to vapor, maintaining the sensory, biological, and nutritional characteristics of the dried product close to the product in fresh. This processing method also appears as an effective way for conservation of the product for a longer period. Thus, freeze-dried red dragon yoghurt containing probiotics might be a new concept of lactose-free, high nutrient dairy products, that containing betacyanin bioactive components from the fruit and probiotics [5]. Besides, the water reduction in yogurt contributes to greater preservation and facilitates transport and packaging due to the reduced weight of the product. Another major advantage is in the economic aspect when low storage temperatures are not required, like those used in the conservation of traditional products, thus eliminating the need for cold chains during storage and distribution [1]. Additionally, freeze-drying preserves much of yoghurt culture, especially probiotic culture, which requires in viable form at a certain number, since the drying process is performed at low temperatures [6].

Based on the yoghurt industrial production, freeze-dried red dragon yoghurt should be prepared by the method of set yoghurt from milk powder by the following steps: milk powder was mixed with stabilizer at $40{ }^{\circ} \mathrm{C}$, cold down and recombined at $4{ }^{\circ} \mathrm{C}$ for $24 \mathrm{~h}$, heated to homogenization temperature at $70{ }^{\circ} \mathrm{C}$, pasteurized at $90{ }^{\circ} \mathrm{C}$ for $5 \mathrm{~min}$ for structure stabilization, cooled to the desired inoculation temperature (typically $42{ }^{\circ} \mathrm{C}$ ), mixed with culture and poured to the packaging, incubation until coagulation, cooling down to $4{ }^{\circ} \mathrm{C}$ for aging and storage for 24 hours at least [7]; the yoghurt was mixed with minced red dragon fruit and freeze-dried to obtain the final products. In order to shorten the drying time for energy saving, the dry matter of the incoming product should be the highest possible. However, too high dry matter may lead to some technical problems in yoghurt fermentation and/or inappropriate texture of the final product. Besides, the yoghurt industrial processing has many complicated steps such as recombination, adding stabilizer, long time pasteurization, homogenization, and aging to increase the water-holding capacity and yoghurt texture [8]. For freeze-dry processing yoghurt, those processing steps might possibly be eliminated. Besides, the yoghurt production should be produced from milk powder to control the dry matter in the product. Therefore, this study aimed to develop a suitable process to produce freeze-dried red dragon yoghurt containing viable probiotic based on conventional yoghurt processing method and freeze-drying process.

\section{Experimental Methods}

\subsection{Yoghurt Manufacture}

White plain skim yoghurt was prepared as described by Tetra Pak, 2012 [7]. Yoghurt base was reconstituted and prepared from skim milk powder ( $12 \%$ or $24 \%$ of milk solids content), $4 \%$ of sucrose, without adding any stabilizer as in industrial processing. After heating at $95{ }^{\circ} \mathrm{C}$ for $5 \mathrm{~min}$, the mixes were cooled in a water bath to the inoculation temperature of $42{ }^{\circ} \mathrm{C}$. The commercial starter ABY10 (Chr Hansen, Denmark) including Bifidobacterium BB12; Lactobacillus acidophilus LA-5; Lactobacillus delbrueckii subsp bulgaricus; Streptococcus thermophilus was added at a concentration recommended by the manufacturer. The inoculated milk was poured into $200-\mathrm{g}$ plastic cups with lids and incubated at $42{ }^{\circ} \mathrm{C}$. Incubation was ended when the $\mathrm{pH}$ of samples reached 4.7. During the fermentation, the acidity and $\mathrm{pH}$ of the sample were measured. After incubation, yogurts were immediately cooled on ice water and stored at $4{ }^{\circ} \mathrm{C}$, ready for freeze-dried processing.

Red dragon fruits (Hylocereus polyrhizus) with an average weight of $0.4-0.6 \mathrm{~kg}$ were obtained from Lap Thach, Vinh Phuc. The selected fruits were all at commercial maturity level; without damage, insect and foreign matter. The fruits were transferred to Laboratory of Department of Food Technology and storage at $4{ }^{\circ} \mathrm{C}$ not more than 3 days. Red dragon fruits were rinsed with tap water to remove dirt and residues followed by air-dried [3]. Then, the skin of fruits was peeled, the flesh was minced and mixed with plain yoghurt [8].

Prepared yoghurt and commercial plain yoghurt (as a control sample, Vinamilk yoghurt (Vinamilk Co., Vietnam)) were mixed with $30 \%(\mathrm{w} / \mathrm{w})$ of fresh dragon fruit and poured into a cubic mould of $1.2 \times 1.2 \times 1.2 \mathrm{~cm}$, freeze at $-20{ }^{\circ} \mathrm{C}$ for 4 hours, and dried by Freeze - dryer system (FreezonePlus 18 liter, Labconco, USA) at 0.14 mbar for 24 hours until the final product containing less than $5 \%$ of water. The final dried products were investigated by structure analysis and the sensory test. 


\subsection{Yoghurt Product Analysis}

Determination of Titratable Acidity using Thorner $\left({ }^{\circ} \mathrm{T}\right)$ AOAC 947.05 [9].

A textural parameter - yoghurt hardness- was determined using Texture Profile Analysis (TPA) Instron TA.TX2 with mechanical compression of a food. The peak force during the first compression cycle is defined as hardness. Sample of dried yoghurt was prepared with a height of $50 \mathrm{~mm}$ contained in a plastic jar. The circular probe (diameter of $20 \mathrm{~mm}$ ) was used; penetration speed, $1 \mathrm{~mm} / \mathrm{s}$; penetration distance, $20 \mathrm{~mm}$ into the surface. The puncture gap of the probe into the sample was fixed by $20 \mathrm{~mm}$ [10].

\section{Sensory Evaluation}

The samples were applied for preference tests by the students of the School of Biotechnology and Food Technology, Hanoi University of Science and Technology, Vietnam. Yoghurt samples were served in white disc at room temperature $\left(20 \pm 1{ }^{\circ} \mathrm{C}\right)$. All samples were marked with 3-digit codes, and the order of presentation of samples was randomized for each panelist. The panelists evaluated the appearance, aftertaste, sourness, yoghurt sour taste, dragon sour taste, yoghurt sweetness, general sweetness, sticky, firmness, texture, dragon flavor, yoghurt flavor, general flavor using a point hedonic scale (1 point for "dislike extremely" and 7 points for "like extremely") [11]. The results were analyzed by ANOVA analysis.

\section{Bacterial count}

Total lactic acid bacteria were counted at inoculation time, after fermentation (before drying), after drying, and in storage time by plate count method using medium de Man, Rogosa Shape (MRS) at $37{ }^{\circ} \mathrm{C}$ for 48 hours and calculate in cfu/g dry matter [12].

\section{Betacyanin analysis}

The sample was diluted the buffer $[0,1 \mathrm{M}$ citric acid $(30 \mathrm{~mL})$ and $0,2 \mathrm{M}$ sodium phosphate $(70 \mathrm{~mL})$

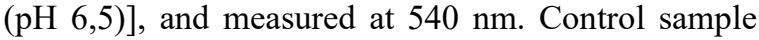
was the buffer. Betanin $(\mathrm{Bc})$ were quantified using a UV- spectrophotometer (APEL PD-303S, Japan) by applying the equation:

$$
B c\left(\mathrm{mg} \mathrm{L}^{-1}\right)=\left(A^{*} F^{*} M W^{*} 1000 / \varepsilon . L\right)
$$

where $A$ is the absorption value at $\lambda \max (540 \mathrm{~nm}), F$ is the dilution factor, $M W$ is the molecular weight of betanin (550 g mol-1), $\varepsilon$ is the molar extinction coefficient of betanin $\left(60,000 \mathrm{~mol}^{-1} \mathrm{~cm}^{-1}\right)$, and $L(\mathrm{~cm})$ is the pathlength of the cuvette. All determinations were carried out in triplicate [5].

\section{Results and Discussion}

\subsection{Effect of the Increased Dry Milk Content on the Yoghurt Fermentation}

To develop a new product freeze-dried red dragon fruit yoghurt containing probiotics, the conventional yoghurt fermentation process was applied, followed by the mix of fresh dragon fruit and freeze-drying. Based on the desired product properties, the preparation yoghurt base was modified to minimize the processing steps and equipment such as follows (1) produce the yoghurt base from skim milk powder instead of fresh milk that makes the initiative in manufacturing; (2) do not use homogenizer mixer and reconstitute steps that required a complicated system and equipment; (3) eliminate homogenization step; (4) do not add any additives such as gelatin, gellan gum, emulsifier, etc. often used to prevent visual whey separation in yoghurt (5) using probiotic starter for fermentation to obtain final product containing probiotic; (6) increase the milk dry content in yoghurt aimed to reduce the fermentation time and the dehydration time. The freeze-dried red dragon yoghurt was prepared from white plain to skim yoghurt base by skim milk powder at $12 \%$ or $24 \% \mathrm{~m} / \mathrm{m}$ of milk solids content. The acidification process during yogurt fermentation can be monitored by $\mathrm{pH}$ measurement and coagulation time, the fermentation was finished when the lactose in the milk converted to lactic acid, a $\mathrm{pH}$ value below 4.6 is reached (Fig. 1a), and the milk is coagulated [8].

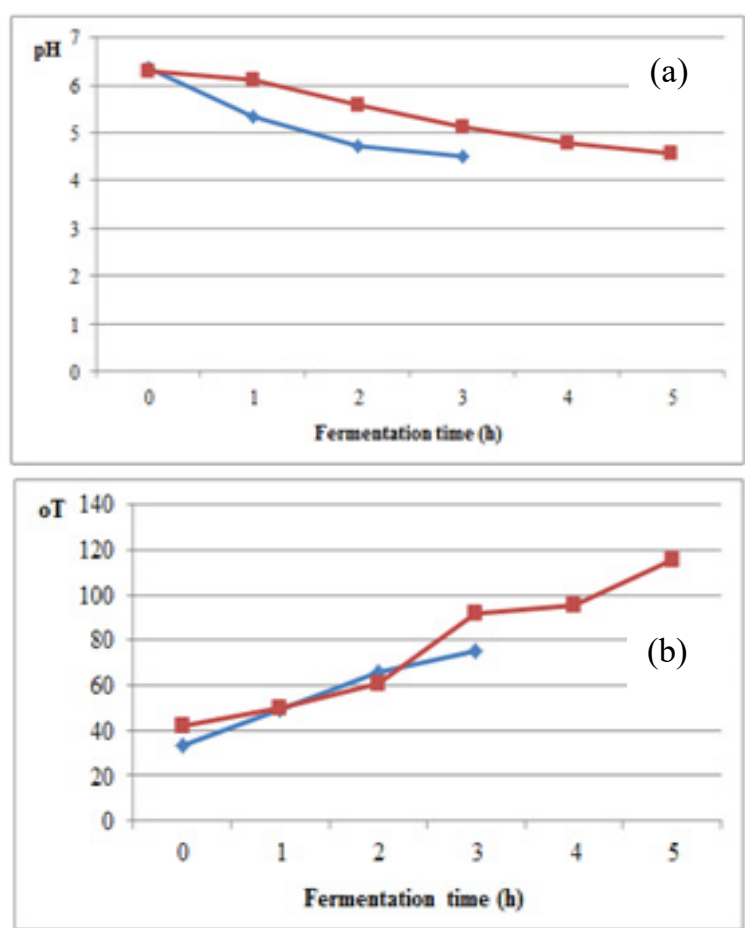

Fig.1. Effect of dry milk content on the plain yoghurt fermentation (a: $\mathrm{pH}$ changes during the fermentation; b: Acidity changes during the fermentation) (skim milk liquid with $12 \%(\diamond)$ and $24 \%(\square)$ of milk solid content) 
On contrary to our expectation, the coagulation time in the sample containing $24 \%$ of milk solids content ( 5 hours) was longer than that of $12 \%$ milk solids concentration (3 hours) (Fig. 1). Also found in Fig 1, prolongation of fermentation time resulted in the higher acidity content (Fig. 1b) that might be affected the acceptance taste of the final products. The results suggested the use of $12 \%$ milk solid content to produce a plain yoghurt base for further processing.

\subsection{Effect of Modified Yoghurt Processing Protocol on the Acceptance of the Final Freeze-Dried Red Dragon Yoghurt Product}

Freeze-dried red dragon yoghurt products were prepared from white plain yoghurt from Vinamilk (control sample), white skim yoghurt with $12 \%$ (sample 1), and 24\% (sample 2) of milk solid contents. The texture and sensorial characterization were evaluated.

The texture is one of the most important properties connected to product quality [4]. The freeze-drying process allows nutritional and sensorial qualities from both yoghurt and red dragon to be retained [13]. Thus, sensory attributes such as the total evaluation, appearance, aftertaste, sourness, yoghurt sour taste, dragon sour taste, yoghurt sweetness, general sweetness, sticky, firmness, texture, dragon flavor, yoghurt flavor, general flavor were evaluated using a point hedonic scale (1 point for "dislike extremely" and 7 points for "like extremely").

The consumer acceptance of new Freeze-dried red dragon yoghurt product made from milk powder with $12 \%$ and $24 \%$ of dry matter and from the control sample using Vinamilk plain yoghurt was demonstrated in Fig. 3. The general sensory acceptance score were 5.25, 4.98, and 5.4 respectively The preference test by Anova analysis showed no significant difference in the samples $(p>0.05)$. Besides, the increase in the solid matter in yoghurt led to an increasing in the hardness (Fig. 2). Thus, the $12 \%$ solid matter in yoghurt from skim milk powder was chosen as a sample to produce freezedried red dragon yoghurt product.

\subsection{Bacteria counts and betacyanin content during processing and storage of freeze-dried yoghurt}

In dairy manufacture, freeze-frying technology stands out as the most efficient method resulting in good quality products, maintenance of viable microorganisms and bioactive components [1]. The survival of lactic acid bacteria and betacyanin content were evaluated in yoghurt sample and final product after freeze-drying and during storage at room temperature up to 30 days.

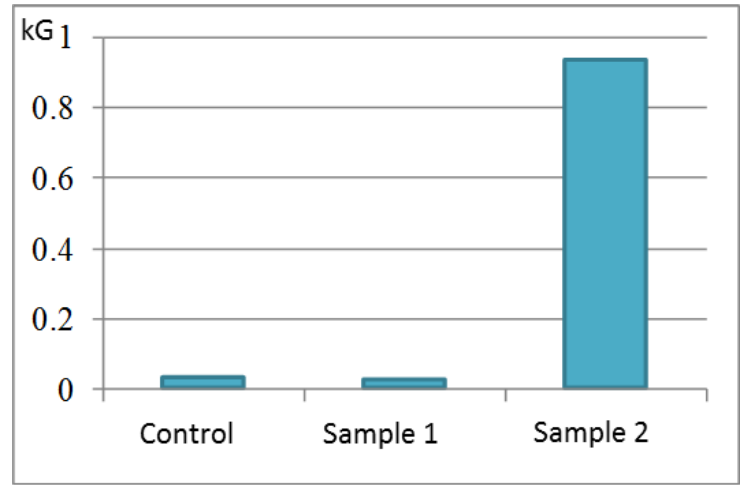

Fig. 2. Texture analysis of freeze-dried red dragon fruit yoghurt products (sample 1: Freeze-dried red dragon yoghurt product from $12 \%$ of dry matter; sample 2: Freeze-dried red dragon yoghurt product from $24 \%$ of dry matter)

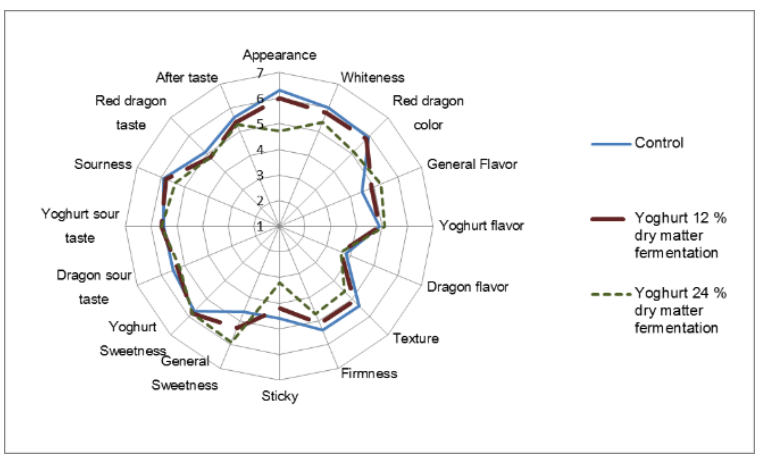

Fig. 3. Sensory assessment of freeze-dried red dragon fruit yoghurt products

Table 1 indicated that freeze-drying process resulted in no significant differences in terms of viability bacteria and betacyanin content. Thus, freeze-drying is suitable to prevent the betacyanin content and survival of antibiotic bacteria in the products for at least 30 days.

Table 1. Viability of bacteria counts and Betacyanin content in freeze dried yoghurt product

\begin{tabular}{|l|l|l|l|l|l|}
\hline & $\begin{array}{l}\text { Before } \\
\text { fermentation }\end{array}$ & $\begin{array}{l}\text { Before } \\
\text { drying }\end{array}$ & After drying & $\begin{array}{l}15 \text { days } \\
\text { storage }\end{array}$ & $\begin{array}{l}30 \text { days } \\
\text { storage }\end{array}$ \\
\hline $\begin{array}{l}\text { Bacteria counts } \\
\text { (cfu/g dry matter) }\end{array}$ & $1.4 \times 10^{7}$ & $3.0 \times 10^{7}$ & $2.9 \times 10^{7}$ & $2.3 \times 10^{7}$ & $1.7 \times 10^{7}$ \\
\hline $\begin{array}{l}\text { Betacyanin } \\
\text { (mg/g dry matter) }\end{array}$ & $0.830 \pm 0.004$ & $0.412 \pm 0.019$ & $0,406 \pm 0.011$ & $0.387 \pm 0.026$ & $0,336 \pm 0.023$ \\
\hline
\end{tabular}


From the results of this study, instead of very complicated yogurt preparation by the traditional yoghurt processing method [7], the freeze-dried red dragon yoghurt was made by the following steps: (1) plain yoghurt preparation: skim milk $12 \%$ dry matter and $4 \%$ sucrose were mixed, heated at $95{ }^{\circ} \mathrm{C}$ for $5 \mathrm{~min}$, cooled down to $42{ }^{\circ} \mathrm{C}$, followed by the addition of commercial probiotic bacteria stater, them fermented for 3 hours until the $\mathrm{pH}$ reached to 4.6 and the milk coagulated (2) mixed with $30 \%$ red dragon fruit, molding in the tray (3) Freeze at $-20{ }^{\circ} \mathrm{C}$ for 4 hours (4) Freeze-drying and packaging. The product can be stored at room temperature in a plastic bag. Comparing with the industrial yoghurt processing method, the recent yoghurt procedure was prepared without stabilizer addition, recombination, homogenization, and aging steps and respectively equipment for those steps.

Freeze-dried yoghurt has been developed in Italia from 2007 as a satisfying, calcium-rich food with nutritional and therapeutic for consumption in space [13]. The product was also well researched to obtain an alternative dairy product rich in nutrition [1]. However, this is the first report related to the production of freeze-dried yoghurt containing probiotics and bioactive components from fresh dragon fruit on laboratory scale.

\section{Conclusion}

The present work successfully proposed the protocol in laboratory scale to produce a new nutritional and health benefits dairy product, freezedried red dragon yoghurt containing viable probiotic and betacyanin - bioactive component obtained from red dragon fruit- by eliminating many processing steps and equipment, food additive addition and the need for cold chain during distribution and storage. The bioactive compound and microbiological characteristics were preserved after 30 days of storage.

\section{Acknowledgments}

This work was supported by Hanoi University of Science and Technology under the Project T2018-PC-204

\section{References}

[1] G. Santos, T. P. Nunes, M. A. A. P. Silva, A. Rosenthal and A. A. C. Pagani, Development and acceptance of freeze-dried yogurt powder yogurt, International Food Research Journal, 25(3), (2018), $1159-1165$
[2] G. D. Iller, J. K. Jarvis, and L. D. Mcbean. Handbook of Dairy Foods and Nutrition, Cambridge: CRC Press 3rd ed., pp.10-40, 2006 https://doi.org/10.1201/9781420004311

[3] Y. M. Wong and L. F. Siow, Effects of heat, pH, antioxidant, agitation and light on betacyanin stability using red-fleshed dragon fruit (Hylocereus polyrhizus) juice and concentrate as models, J. Food Sci. Technol. 52(5) (2015) 3086-3092. https://doi.org/10.1007/s13197-014-1362-2

[4] V. Valentina Pratiwi, A. R. Hsia, P. Y. Tseng, H. T. Hsieh, and C.C. Chen, Sensorial characterization of foods before and after freeze-drying, Austin Food Sciences, 1(6) 2016, 1-5.

[5] K. M. Herbach, Effects of processing and storage on juice colour and betacyanin stability of purple pitaya (Hylocereus polyrhizus) juice, European Food Research Technology, 224 (2007) 649-658. https://doi.org/10.1007/s00217-006-0354-5

[6] F. E. McDonough, A. D. Hitchins N. P. WONG, Effects of yogurt and freeze - dried yogurt on growth stimulation of rats, J. Food Science, 47(5) (1982), pp. 1463-1465.

https://doi.org/10.1111/j.1365-2621.1982.tb04961.x

[7] Dairy Processing Handbook, Tetra Pak 2012, Tetra Pak Processing Systems AB. S-221 86 Lund, Sweden.

[8] V. T. Trang, N. T. T Nguyen, N. V. Hung, N. T. Cuong, H. Q. Tuan, N. T. Thao, N. T. Hanh, N. T. H. Duc, C. K. Son, N. V. Thai, N. T. Hung, Stability of betacyanin in red dragon fruit (hylocereus polyrhizus) juice obtained from Lap Thach, Vinh Phuc province. Journal of Sci. and Tech. Technical Universities, Vol. 140 (2020), pp. 71-76 (in Vietnamese).

[9] Official Methods of Analysis, 15th ed., Association of Official Analytical Chemists, Arlington, VA1990

[10] Ozcan T., Determination of yogurt quality by using rheological and textural parameters, Int. Conf. Nutr. Food Sci. Vol. 53 (2013) pp. 118-122.

[11] A. Leahu, C. E. Hretcanu, Study on the acceptability of yoghurt with carrot juice, Food Environ. Saf. XVI (2017), pp. 104-110.

[12] Le Thanh Mai, Analytical methods in fermentation technology, Science and Technics Publishing House, 2007, pp. 166-169, (in Vietnamse).

[13] V. Elena, D. T. Manuela, M. L. Mara, M. Enrico, N. D. Paolo, Preparation of freeze-dried yoghurt as a space food. Journal of Food Engineering Vol. 80 (2007) pp. 402-407. 